Dhaka Univ. J. Biol. Sci. 20(1): 71-80, 2011 (January)

\title{
CHARACTERIZATION AND CLASSIFICATION OF SOME INTENSIVELY CULTIVATED SOILS FROM THE GANGES RIVER FLOODPLAIN OF BANGLADESH
}

\author{
M.M. Hossain ${ }^{1}$, Z.H. KHAN*, M.S. HusSAIN AND A.R. MAZumder \\ Department of Soil, Water \& Environment, University of Dhaka, Dhaka-1000, Bangladesh
}

Key words: Ganges river floodplain, Characterization, Classification, Cultivated soils

\begin{abstract}
Most of the soil samples from four pedons representing some extensive soil series from the Ganges river floodplain of Bangladesh found to be heavy textured with clay content averaging from 43 to 55 per cent up to a depth of one meter. The soils had neutral to alkaline reaction with high percentage of base saturation. Because of seasonal flooding ranging from two - three months the soils have developed redoximorphic features including redox concentration in the middle zone and a redox depletion in the lower zone of the profiles. The seasonal submergence and drying are the most active factors in developing the morphogenetic features in these soils. Smectite was the dominant clay mineral followed by mica and kaolinite with small quantities of vermiculites and interstratified minerals. The minerals in the clay fraction of the soils appear to be inherited from alluvial parent materials with very little in situ mineral transformation. The soils were characterized at the family categoric level of USDA soil taxonomy.
\end{abstract}

\section{Introduction}

The Ganges floodplain in Bangladesh represents a typical riverine landscape which covers about one-fifth of its total land area covering parts of greater Rajshahi, Pubna, Dhaka, Barisal, Khulna and whole of Kushtia, Jessor and Faridpur districts. It comprises the active floodplain of the Ganges river and the adjoining meander floodplain landscape of ridges, basins and old channels. Three physiographic units, such as the Ganges river floodplain, Ganges tidal floodplain and Gopalganj-Khulna beels have been identified in this vast floodplain. The soils developed on this floodplain differ in their morphological, physical and chemical properties mainly due to its mineralogy, age of sedimentation, relief and drainage. ${ }^{(1)}$ Clay soils predominate in basin and on many places of the floodplain but silt and occasionally sand occupy higher ridge crests. The sediments of the Ganges delta are calcareous and fine textured. The calcareous sediments of the Ganges floodplain in many places have been decalcified and the mechanism of this decalcification process has been illustrated by Brammer. ${ }^{(2)}$ Being fabulously fertile and densely populated, the soils of the Ganges delta have been the subject of extensive use for rice paddy cultivation for a long time.

*Corresponding author. <khanzh_du@yahoo.com>. ${ }^{1}$ Bangladesh Post Office, Directorate of Post, Dhaka-1000, Bangladesh. 
Few sporadic studies dealing with the morphological and mineralogical properties of the soils and sediments of the Gangetic alluvium in Bangladesh and India have been reported. ${ }^{(3,4,5)}$ Properties of soils having agricultural significance are considered at the family level, the fifth category of USDA soil taxonomy. Soils of Bangladesh could not be characterized in the family categoric level due to lack of mineralogical data. Hence more mineralogical study is needed to characterize the soils to understand the mineralogical impacts on soil productivity and also to understand the mineral transformations and degree of soil development. Moreover, kknowledge about soil characterization is essential for good land evaluation, which is prerequisite for sound land management. Since these floodplain soils are intensively used for growing paddy rice, their mineralogy, morphology and taxonomic classification should be meticulously studied for better understanding of maintaining sustainability in soil health as well as crop production.

The present paper reports some salient morphological, physical, chemical and clay minerlogical properties for charaterization and classification of four extensively occurring soil pedons from the Ganges river floodplain of Bangladesh.

\section{Materials and Methods}

The Ganges river floodplain soils in Bangladesh represents nearly level to gently undulating landscape of floodplain ridges, inter-ridge depressions, infilled channels and basins consisting of unconsolidated river borne alluvium lying between 10 and 15 meters above the mean sea level. The soils here were traditionally used for the cultivation of rice and jute. The climate of the area is humid tropical monsoon (moist subhumid megathermal), with a mean annual temperature of $25.5^{\circ} \mathrm{C}$ and an annual rainfall of around $2250 \mathrm{~mm} .^{(1)}$ The temperature regime is hyperthermic and most of the agricultural fields have udic/aquic moisture regimes.

Four extensive soil series viz., Amjhupi, Gangni, Garuri, and Sara in the Ganges river floodplain of Bangladesh have been selected for this study. All these soils are flooded annually for varying periods during the rainy season and used mainly for cultivation of rice and jute. The information on soil sampling sites and their environmental conditions are presented in Table 1. Pits were dug in the selected sites and soil profiles were described in the field according to the procedures outlined in the Soil Survey Manual. ${ }^{(6)}$ A total of 27 soil samples were collected from the four selected profiles on genetic horizon basis. The soil samples were duly processed and analysed in the laboratory for determining their physical, chemical and clay mineralogical properties.

The soil $\mathrm{pH}$ was determined following the method of Jackson ${ }^{(7)}$ and particle size analysis was carried out following the method reported by Black. ${ }^{(8)}$ Organic carbon was measured by Walkley and Black's wet oxidation method. ${ }^{(7)}$ Cation exchange capacity (CEC) was measured with ammonium acetate method at $\mathrm{pH} 7.0 .^{(7)}$

For clay mineralogical analysis the soil samples were treated with hydrogen peroxide to decompose organic matter. The samples were finally treated with sodium dithionite-citratebicarbonate to remove free oxides of iron and manganese. ${ }^{(9)}$ Thereafter, the samples were 
dispersed and clay $(<2 \mu \mathrm{m})$ fraction was separated from soil suspension by centrifugation and decantation method. The exchange complex of each clay sample $(<2 \mu \mathrm{m})$ was $\mathrm{Mg}$ - and $\mathrm{K}$ saturated by repeated washings with normal solutions of $\mathrm{MgCl}_{2} \cdot 6 \mathrm{H}_{2} \mathrm{O}$ and $\mathrm{KCl}$, respectively. Four slides of each pre-treated soil clays were prepared from samples of (1) Mg-saturated and air-dried, (2) K saturated and air-dried, (3) Mg-saturated and glycerol solvated and (4) K-saturated and heated at $550^{\circ} \mathrm{C}$ for at least 2 hours. These slides were scanned with GEOL X-ray diffractometer with $\mathrm{Ni}$ filtered $\mathrm{Cu} \mathrm{K} \alpha$ radiation (at $30 \mathrm{kV}, 40 \mathrm{~mA}$ ) at a scanning speed of $2^{\circ} 2 \theta$ per minute from $2^{\circ}$ to $30^{\circ} 2 \theta$. The clay minerals in the clay fractions were identified following the method of Jackson. ${ }^{(10)}$ A semi-quantitative estimation of minerals in the clay fraction of the soils were carried out following the method of Johnson et al. ${ }^{(11)}$

Table 1. Location and environmental conditions of the soils.

\begin{tabular}{lllll}
\hline Characteristic & \multicolumn{4}{c}{ Soil series } \\
\cline { 2 - 5 } features & Amjhupi & Gangni & Garuri & Sara \\
\hline Location & Jhikargacha & Jhikargacha & Jessore sadar & Jessore sadar \\
(Latitude and & upazila & upazila & upazila & upazila \\
longitude) & $\left(23^{\circ} 10^{\prime} \mathrm{N}\right.$ and & $\left(23^{\circ} 09^{\prime} \mathrm{N}\right.$ and & $\left(23^{\circ} 07^{\prime} \mathrm{N}\right.$ and & $\left(23^{\circ} 12^{\prime} \mathrm{N}\right.$ and \\
& $\left.89^{\circ} 06^{\prime} \mathrm{E}\right)$ & $\left.89^{\circ} 08^{\prime} \mathrm{E}\right)$ & $\left.89^{\circ} 11^{\prime} \mathrm{E}\right)$ & $\left.89^{\circ} 15^{\prime} \mathrm{E}\right)$ \\
Area (ha) & $1,09,737$ & $1,01,255$ & $1,82,732$ & $1,89,236$ \\
Parent material & Ganges river & Ganges river & Ganges river & Ganges river \\
& alluvium & alluvium & alluvium & alluvium \\
Relief & Nearly level ridge & Nearly level ridge & Nearly level basin & Nearly level ridge \\
Land type & Medium high land & Medium low land & Medium low land & Medium high land \\
Vegetation/ & Aus/Jute-Rabi & Aus/Jute-T. aman & T. aman-Fallow/ & Aus/Jute-Rabi \\
land use & & & T.aman-Boro & \\
Taxonomic & Aeric & Aeric & Aeric & Aquic \\
classification* & Endoaquept & Endoaquept & Endoaquept & Eutrochrept \\
\hline
\end{tabular}

*Subgroups of US Soil Taxonomy. ${ }^{(13)}$

\section{Results and Discussion}

The soil matrix had a mixture of olive brown $(2.5 \mathrm{Y} 4 / 4)$, light olive brown $(2.5 \mathrm{Y} 5 / 4 ; 2.5 \mathrm{Y}$ $5 / 6$ ), greyish brown (2.5Y 5/2) and dark grey (5Y 4/1) colours with abundant quantities of variously coloured mottles prominant in the middle zone of the profiles (Table 2). The alternate wetting and drying conditions in these soils resulted in the reduction and subsequent release of iron oxides, which were accumulated in the form of brown, light olive brown, dark brown and dark yellowish brown mottles in the middle zone of the profiles. Redoximorphic features associated with wetness resulted from alternating periods of reduction and oxidation of iron and manganese compounds in the soils. ${ }^{(12)}$ The redox depletion at the surface contributed to the development of dark grey colour to the surface soils. Redox concentrations in the subsoil zone were responsible for the formation of mottles. 
Table 2. Some morphogenetic features of soils from the Ganges river floodplain.*

\begin{tabular}{|c|c|c|c|c|c|c|c|}
\hline \multirow{2}{*}{$\begin{array}{l}\text { Soil } \\
\text { series }\end{array}$} & \multirow[t]{2}{*}{ Horizon } & \multirow{2}{*}{$\begin{array}{l}\text { Depth } \\
\text { (cm) }\end{array}$} & \multicolumn{2}{|c|}{ Munsell colour } & \multirow{2}{*}{$\begin{array}{l}\text { Field } \\
\text { textural } \\
\text { class }\end{array}$} & \multirow[t]{2}{*}{ Structure } & \multirow{2}{*}{$\begin{array}{c}\text { Effervescence } \\
\text { (dilute } \mathrm{HCl} \\
\text { treatment) }\end{array}$} \\
\hline & & & $\begin{array}{l}\text { Matrix } \\
\text { (moist) }\end{array}$ & Mottles & & & \\
\hline \multirow[t]{7}{*}{ Amjhupi } & Apg & $0-12$ & $2.5 \mathrm{Y} 5 / 4$ & $f_{1} d g$ & sicl & $\mathrm{m}$ & eo \\
\hline & Bwg1 & $12-32$ & $2.5 \mathrm{Y} 4 / 4$ & $\mathrm{c}_{1} \mathrm{~d}$ og & sic & $3 c-m$ abk & eo \\
\hline & Bwg2 & $32-57$ & $2.5 \mathrm{Y} 4 / 4$ & $f_{1} d d b$ & $\mathrm{c}$ & $3 \mathrm{c}-\mathrm{m}$ abk & eo \\
\hline & $2 \mathrm{Cg}$ & $57-75$ & $2.5 \mathrm{Y} 5 / 4$ & $f_{1} d g b$ & $\mathrm{cl}$ & $\mathrm{m}$ & ev \\
\hline & $3 \mathrm{Ab}$ & $75-90$ & $2.5 \mathrm{Y} 5 / 4$ & $f_{1} d g b$ & sic & $\mathrm{m}$ & ev \\
\hline & $3 \mathrm{Bwgb}$ & $90-113$ & $2.5 \mathrm{Y} 5 / 6$ & $\mathrm{c}_{1} \mathrm{dg}$ & sic & $2 \mathrm{c} \mathrm{pr} / 2 \mathrm{c}-\mathrm{m}$ abk & ev \\
\hline & $3 \mathrm{Cb}$ & 113-129 & $2.5 \mathrm{Y} 5 / 6$ & $\mathrm{c}_{1} \mathrm{~d} \mathrm{db}$ & sicl & $\mathrm{m}$ & ev \\
\hline \multirow[t]{7}{*}{ Gangni } & Apg1 & $0-10$ & $2.5 \mathrm{Y} 5 / 2$ & - & sic & $\mathrm{m}$ & eo \\
\hline & Apg2 & $10-17$ & $2.5 \mathrm{Y} 5 / 2$ & $f_{1} d d y b$ & $\mathrm{c}$ & $\mathrm{m}$ & eo \\
\hline & Bwg1 & $17-48$ & $2.5 \mathrm{Y} 4 / 4$ & $c_{1} d g$ & $\mathrm{c}$ & $3 \mathrm{c} \mathrm{pr} / 3 \mathrm{c}-\mathrm{m}$ abk & eo \\
\hline & Bwg2 & $48-62$ & $2.5 \mathrm{Y} 4 / 4$ & $\mathrm{c}_{1} \mathrm{dg}$ & $\mathrm{c}$ & $3 \mathrm{c} \mathrm{pr} / 3 \mathrm{c}-\mathrm{m}$ abk & eo \\
\hline & Bwg3 & $62-88$ & $2.5 \mathrm{Y} 4 / 4$ & $\mathrm{f}_{1} \mathrm{dg}$ & sic & $2 \mathrm{c} \mathrm{pr}$ & es \\
\hline & $\mathrm{Cg} 1$ & $88-97$ & $2.5 Y 5 / 4$ & $f_{1} d g$ & sicl & $\mathrm{m}$ & ev \\
\hline & $\mathrm{C} 2$ & 97-192 & $2.5 \mathrm{Y} 5 / 4$ & - & sil & $\mathrm{m}$ & ev \\
\hline \multirow[t]{7}{*}{ Garuri } & Apg1 & $0-10$ & $5 Y 4 / 1$ & $f_{1} d d b$ & sic & $\mathrm{m}$ & eo \\
\hline & Apg2 & $10-16$ & $5 Y 4 / 1$ & $\mathrm{f}_{1} \mathrm{~d} \mathrm{db}$ & $\mathrm{c}$ & $\mathrm{m}$ & eo \\
\hline & Bw1 & $16-26$ & $2.5 \mathrm{Y} 4 / 4$ & $c_{1} d d b$ & $\mathrm{c}$ & $3 \mathrm{c} \mathrm{pr} / 3 \mathrm{c}-\mathrm{m}$ abk & eo \\
\hline & Bw2 & $26-35$ & $2.5 \mathrm{Y} 4 / 4$ & $\mathrm{f}_{1} \mathrm{~d} d \mathrm{~b}$ & $\mathrm{c}$ & $3 \mathrm{c} \mathrm{pr} / 3 \mathrm{c}-\mathrm{m}$ abk & es \\
\hline & Bw3 & $35-43$ & $2.5 \mathrm{Y} 4 / 4$ & $\mathrm{c}_{1} \mathrm{~d} \mathrm{db}$ & sic & $2 \mathrm{c} \mathrm{pr} / 2 \mathrm{c}-\mathrm{m}$ abk & ev \\
\hline & $\mathrm{C} 1$ & $43-79$ & $2.5 \mathrm{Y} 4 / 4$ & - & sicl & - & ev \\
\hline & $\mathrm{Cg} 2$ & $79-146$ & $2.5 \mathrm{Y} 4 / 4$ & $\mathrm{f}_{1} \mathrm{dg}$ & sic & - & ev \\
\hline \multirow[t]{6}{*}{ Sara } & Apg & $0-15$ & $2.5 \mathrm{Y} 5 / 2$ & $c_{1} d d y b$ & sil & $\mathrm{m}$ & es \\
\hline & Bwg1 & $15-35$ & $2.5 \mathrm{Y} 4 / 4$ & $c_{1} d g b$ & sil & $\mathrm{m}$ & ev \\
\hline & Bw2 & $35-65$ & $2.5 \mathrm{Y} 4 / 4$ & $f_{1} d d y b$ & sil & $1 \mathrm{c} \mathrm{pr}$ & ev \\
\hline & $\mathrm{C} 1$ & $65-98$ & $2.5 \mathrm{Y} 4 / 4$ & $c_{1} d$ dyb & sicl & $1 \mathrm{c} \mathrm{pr}$ & ev \\
\hline & $\mathrm{C} 2$ & $98-120$ & $2.5 \mathrm{Y} 5 / 4$ & $f_{1} d d y b$ & sil & $\mathrm{m}$ & ev \\
\hline & $\mathrm{C} 3$ & $120-135$ & $2.5 \mathrm{Y} 5 / 4$ & $\mathrm{f}_{1} \mathrm{~d} \mathrm{db}$ & sic & $\mathrm{m}$ & ev \\
\hline
\end{tabular}

*The abbreviations used are those of USDA system ${ }^{(6)}$

In Sara soil profile there was a weak, very coarse prismatic structure in the B horizon. This horizon has been considered as an incipient cambic horizon. ${ }^{(13)}$ Other three soil profiles had moderate to strong, medium to coarse prismatic and blocky structures in their control section. These structural B horizon have been considered as a cambic horizon. ${ }^{(13)}$ Alternate wet and dry periods favoured the formation of these structural B horizon. ${ }^{(2)}$ All the soils have continuous, thick, grey to very dark grey cutans on ped faces. The coatings on ped faces may possibly be due to mechanical downward washing of materials from the soil surface through cracks when the soils get flooded and ploughed. ${ }^{(2)}$ The textures of the soils vary from silt loam to clay. The consistency was firm, sticky and plastic, which was indicative of moderate water retention of these soils. 
Effervescence with $\mathrm{HCl}$ was noticeable in all the soil profiles which indicates calcareousness of the soils. Strong effervescence was observed below $50 \mathrm{~cm}$ in some soils which indicates the symptom of decalcification.

Silt contents in the soil of Amjhupi and Gangni avarage in the forties, in Garuri it is in the 50s while in Sara it is over 60 per cent (Table 3). The clay content was high in Amjhupi, Gangni and Garuri soils while it was low in Sara soil. These high clay content is a characteristic property of the lower Ganges river floodplain soils of Bangladesh. ${ }^{(2)}$ The vertical and horizontal variation in texture is mainly due to sedimentation rather than weathering.

Table 3. Some physical and chemical properties of the soil.

\begin{tabular}{|c|c|c|c|c|c|c|c|c|}
\hline Soil series & $\begin{array}{c}\text { Sand } \\
\text { content } \\
(\%)\end{array}$ & $\begin{array}{c}\text { Silt } \\
\text { content } \\
(\%)\end{array}$ & $\begin{array}{c}\text { Clay } \\
\text { content } \\
(\%)\end{array}$ & $\begin{array}{c}\text { Organic } \\
\text { carbon } \\
(\%)\end{array}$ & $\begin{array}{c}\mathrm{CEC} \\
{\left[\mathrm{cmol}^{-1} \mathrm{p}^{+}\right)} \\
\left.\mathrm{kg}^{-1}\right]\end{array}$ & $\begin{array}{c}\mathrm{pH} \\
\left(\mathrm{H}_{2} \mathrm{O}\right)\end{array}$ & $\mathrm{BSP}^{*}$ & $\begin{array}{l}\text { Free } \\
\text { lime } \\
(\%) \\
\end{array}$ \\
\hline \multicolumn{9}{|l|}{ Amjhupi: } \\
\hline Range & $2-25$ & $33-57$ & $18-65$ & $0.21-0.76$ & $8.1-29.4$ & $7.3-7.7$ & $88-100$ & $2.0-6.0$ \\
\hline Mean & 14 & 43 & 43 & 30.9 & 19.8 & 7.5 & 95 & 4.0 \\
\hline \multicolumn{9}{|l|}{ Gangni: } \\
\hline Range & $6-21$ & $18-71$ & $15-71$ & $0.18-0.95$ & $7.7-34.3$ & $6.9-7.9$ & $93-100$ & $2.0-7.5$ \\
\hline Mean & 12 & 41 & 47 & 0.43 & 23.0 & 7.4 & 97 & 5.0 \\
\hline \multicolumn{9}{|l|}{ Garuri : } \\
\hline Range & $2-10$ & $30-57$ & $33-68$ & $0.24-1.57$ & $12.8-34.5$ & $7.5-7.6$ & $92-100$ & $3.0-8.0$ \\
\hline Mean & 4 & 51 & 55 & 0.63 & 27.9 & 7.5 & 96 & 5.0 \\
\hline \multicolumn{9}{|l|}{ Sara: } \\
\hline Range & $5-22$ & $42-69$ & $13-53$ & $0.18-0.60$ & $8.5-24.5$ & $7.5-7.7$ & $89-99$ & $3.5-7.5$ \\
\hline Mean & 16 & 62 & 22 & 0.28 & 12.3 & 7.6 & 94 & 6.0 \\
\hline
\end{tabular}

*BSP - Per cent base saturation.

The soils were neutral to alkaline with $\mathrm{pH}$ values ranging from 6.9 to 7.9 (Table 3). The alkaline $\mathrm{pH}$ of the soils might be due to the calcareous nature of parent materials. The organic carbon contents in the soils is low. Low organic carbon content is a common problem in Bangladesh soils, which is possibly due to rapid decomposition of organic matter, caused by cultivation under tropical conditions. The cation exchange capacities and the base saturation percent are high. Free lime content in the soils ranged from 2 to 8 per cent.

X-ray diffractograms (Figs 1-4) of the clay fraction showed the occurrence of both swelling and non-swelling types of clay minerals. The semi-quantitative estimation of clay minerals showed the dominance of smectite which occupied more than $50 \%$ of the clay fraction of the soils followed by mica which occupied about one-third of the clay fraction (Table 4). The presence of mica in the studied soils indicates that the transformation of mica to expanding lattice minerals has been slow. Mica in most soils originated mainly from soil parent materials and tend to weather to other minerals with time. ${ }^{(14)}$ This mineral is generally more prevalent in clay fraction of younger and less weathered soils (Entisols), Inceptisols and Alfisols. ${ }^{(14)}$ 

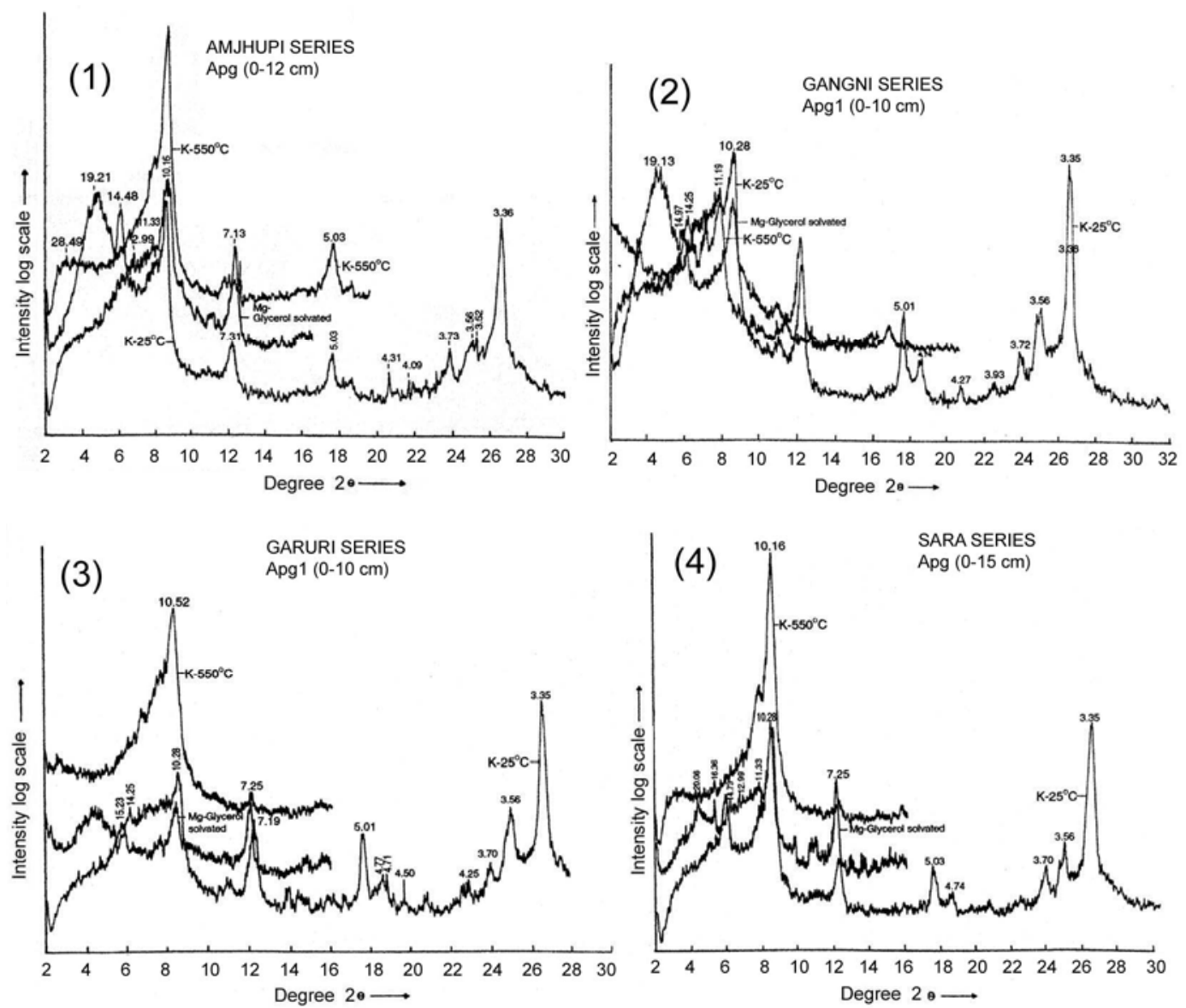

Figs 1-4: 1. X-ray diffractograms of clay samples from Apg horizon of Amjhupi soil series. 2. X-ray diffractograms of clay samples from Apg horizon of Gangni soil series. 3. X-ray diffractiograms of clay samples from Apg horizon of Garuri soil series. 4. X-ray diffractograms of clay samples from Apg horizon of Sara soil series.

Table 4. Semi-quantitative estimates of clay minerals in the clay fraction of surface soils.

\begin{tabular}{lcccccccc}
\hline \multirow{2}{*}{$\begin{array}{l}\text { Soil } \\
\text { series }\end{array}$} & Horizon & \multirow{2}{*}{$\begin{array}{c}\text { Depth } \\
(\mathrm{cm})\end{array}$} & $\begin{array}{c}\text { Clay } \\
\text { content } \\
\end{array}$ & & & \multicolumn{5}{c}{ Clay mineral composition (out of 10)* } \\
\cline { 5 - 9 } & & & & $\mathrm{K}$ & $\mathrm{M}$ & $\mathrm{V}$ & $\mathrm{S}$ & $\mathrm{I}$ \\
\hline Amjhupi & Apg & $0-12$ & 36 & 1.0 & 3.0 & 0.5 & 5.5 & $\operatorname{tr}$ \\
Gangni & Apg1 & $0-10$ & 65 & 1.0 & 2.5 & 0.5 & 6.0 & $\operatorname{tr}$ \\
Gerua & Apg1 & $0-10$ & 57 & 2.0 & 3.0 & $\operatorname{tr}$ & 4.5 & 0.5 \\
Sara & Apg & $0-15$ & 15 & 1.5 & 3.5 & 1.0 & 4.0 & $\operatorname{tr}$ \\
\hline
\end{tabular}

*K - kaolinite, M - mica, V - vermiculite, S - smectite, I - interstratified (11-12 $\AA)$ minerals, $\operatorname{tr}$ - trace $(<0.5)$.

The third dominant mineral in the clay fraction was kaolinite. Kaolinite in the present soils is of allogenic origin. Kaolinite is one of the most widespread clay minerals in the humid tropical soils which is the product of acidic weathering. ${ }^{(15)}$ 
A small quantity of vermiculites and interstratified minerals were present in the clay fraction of all the soils. Occurrence of small quantities of vermiculites in the soils indicates that transformation of mica to expanding lattice minerals has not progressed considerably. White, ${ }^{(16)}$ however noted that vermiculite in Bangladesh soils was formed by transformation of mica. The presence of small quantities of interstratified minerals in the clay fraction of the Ganges floodplain soil is also interesting and needs further study.

Smectites have been reported to be quite abundant in the soils of Gangetic alluvium. ${ }^{(17,18)}$ Moslehuddin and Egashira ${ }^{(19)}$ reported high quantity of smectite $(62-88 \%)$ in the fine clay fractions of the Ganges floodplain soils. They noted that the smectite mineral was mainly of ironrich beidellite type with an estimated chemical formula of $\left(\mathrm{Si}_{6.9} \mathrm{Al}_{1.10}\right)\left(\mathrm{Al}_{2.46} \mathrm{Fe}_{0.99} \mathrm{Mg}_{0.76}\right)$ $\mathrm{O}_{20}(\mathrm{OH})_{4.0} \mathrm{X}_{1.25}$. According to $\mathrm{Brammer}^{(2)}$ the clay minerals in the soils formed on the floodplains of Bangladesh were mostly inherited from their parent materials. According to him, neosynthesis of smectites was possible in the calcareous Gangetic alluvium as the chemical environment (e.g. high $\mathrm{pH}$, high BSP and calcareousness) existing in these soils appeared to be congenial for their formation and persistence. Singh and Misra ${ }^{(20)}$ from their study on a number of soils from the Indo-Gangetic plains noted that the fairly high amount of $\mathrm{Mg}$ in the existing pedochemical environment including high $\mathrm{pH}$ and high base saturation might suggest the persistence of smectite and even vermiculite as an intermediate weathering product.

The studied soils have developed on recent alluvial parent materials where seasonal flooding of various duration and consequent siltation are a common feature during the monsoon months. From the particle size distribution of soils it might be inferred that the parent materials are to some extent heterogeneous in nature and of mixed origin. Morphological features of these soils indicate that their profile development did not proceed far. All the soils under the present investigation appear to be only weakly developed. This may be due to environmental conditions and time factors. The soils may, therefore, be reasonably considered to be in their incipient age of development. Moreover, the nature of parent material, local relief and the seaonal submergence and drying conditions are probably the factors affecting the profile characteristics of the soils. Apart from that the soils have been under rice cultivation for a long time, which disturbed the normal pedogenic processes and helped in the mechanical translocation of finer fractions downward forming a ploughplan at a depth of $5-15 \mathrm{~cm}$, and flood coatings in the subsoil zone. These coatings are not clay skins but are flood coatings or gleyans as called by Brammer. ${ }^{(2)}$ Moreover, annual siltation due to seasonal flooding is a common phenomenon in these soils which hampers pedogenesis.

The seasonal submergence and drying set the conditions of alternate oxidation and reduction which are the most striking feature of the pedochemical environment in these soils. These alternate wetting and drying situations hasten the process of soil profile development. Alternate wet and dry conditions produce vertical cracks leading to big prisms in the soil profiles. With the passage of time, the horizontal cracks and combined effect of flocculation, root penetration, organic matter 
addition and the biotic activity produced angular and sub-angular blocky structures in the studied soils. These structural B horizons have been considered as cambic B horizons. Formation of structure in these soils is relatively faster than in other soils. ${ }^{(2)}$

The reaction of the soils closely follows the course of oxidation-reduction conditions because the soils contain considerable amounts of $\mathrm{Fe}$ and $\mathrm{Mn}$ which are subject to change. The enrichment of free iron (mottlings) in the middle zone of the soil profile is possibly due to these alternate oxidation reduction conditions. This kind of mobilization and fixation of iron in the soil indicates that gleization is probably the pedogenic process. The soils of the Ganges river floodplain are calcareous. The processes of decalcification and calcification are involved in these soils. The soil reaction closely follows the course of oxidation-reduction conditions but as the soils contain lime in considerable amounts the soil $\mathrm{pH}$ is always alkaline.

On the basis of morphological, physical, chemical and clay mieralogical properties the studied soils were characterized according to USDA soil classification system. ${ }^{(13)}$ Based on morphogenetic features and other relevant properties it can be inferred that all the soils show some marks of profile development that have resulted in the formation of a cambic horizon along with an ochric epipedon. Hence, these soils were characterized under Inceptisol order. On the basis of properties associated with wetness and the presence of an ochric epipedon the studied soils were placed into two suborders: Aquepts and Ochrepts.

Table 5. Characterization of soils from the Ganges river floodplain in Bangladesh.

\begin{tabular}{|c|c|c|c|c|c|}
\hline \multicolumn{5}{|c|}{ Soil taxonomy* } & \multirow[t]{2}{*}{ Soil series } \\
\hline Order & Suborder & Great group & Subgroup & Family & \\
\hline \multirow[t]{4}{*}{ Inceptisols } & Aquepts & Endoaquepts & $\begin{array}{l}\text { Aeric } \\
\text { Endoaquepts }\end{array}$ & $\begin{array}{l}\text { Clayey, Smectitic, Nonacid, } \\
\text { Hyperthermic, Aeric } \\
\text { Endoaquepts }\end{array}$ & Amjhupi \\
\hline & & & $\begin{array}{l}\text { Aeric } \\
\text { Endoaquepts }\end{array}$ & $\begin{array}{l}\text { Clayey, Smectitic,Nonacid, } \\
\text { Hyperthermic, Aeric } \\
\text { Endoaquepts }\end{array}$ & Gangni \\
\hline & & & $\begin{array}{l}\text { Aeric } \\
\text { Endoaquepts }\end{array}$ & $\begin{array}{l}\text { Clayey, Mixed, Nonacid, } \\
\text { Hyperthermic, Aeric } \\
\text { Endoaquepts }\end{array}$ & Garuri \\
\hline & Ochrepts & Eutrochrepts & $\begin{array}{l}\text { Aquic } \\
\text { Eutrochrepts }\end{array}$ & $\begin{array}{l}\text { Loamy, Mixed, Nonacid, } \\
\text { Hyperthermic, Aquic } \\
\text { Eutrochrepts }\end{array}$ & Sara \\
\hline
\end{tabular}

*According to USDA Soil Taxonomy. ${ }^{(13)}$

Considering the mechanism by which the aquic moisture regime originated as the basis and the soils got wet, the soils belonging to the Aquept suborder (Amjhupi, Gangni and Garuri series) were placed into Endoaquepts great group. The Sara series belonging to Ochrept suborder can be placed into Eutrochepts great group because of calcareousness of the profile throughout and a base saturation $\left(\mathrm{NH}_{4} \mathrm{OAc}\right)$ of $60 \%$ or more in some horizon between 25 and $75 \mathrm{~cm}$ depths.

At the subgroup level Amjhupi, Gangni and Garuri soil pedons are further characterized as Aeric Endoaquepts subgroup as these soils have $50 \%$ or more matrix colour chroma $\geq 2$ within 75 
cm depth. While the Sara series fit into Aquic Eutrochrepts subgroup because of the presence of grey mottles within $60 \mathrm{~cm}$ from the surface. Finally, on the basis of textural class, clay mineralogical composition, soil reaction class and temperature regime the soils have been classified at the family level of the U.S. Soil Taxonomy (Table 5). This family level classification may serve as useful vehicle for crop production and agrotechnology transfer.

\section{References}

1. FAO-UNDP 1988. Land Resources Appraisal of Bangladesh for Agricultural Development. Report 2 and 3. Agroecological regions of Bangladesh. FAO, Rome.

2. Brammer H 1996. The Geography of the Soils of Bangladesh. The University Press Limited, Dhaka, Bangladesh. pp. 287.

3. Hussain MS, MJ Uddin and S Ferdous 2006. Morphology and clay mineralogy of some hydromorphic soils from the Ganges delta in Bangladesh. J. Asiat. Soc. Bangladesh, Sci. 32(2):257-268.

4. Moslehuddin AZM and K Egashira 1997. Characterization of smectites found in Ganges floodplain soils of Bangladesh. Clay Sci. 10: 151-162.

5. Ghosh SK, G Ghosh and SC Das 1976. Smectite in some Gangetic alluvium soils of West Bengal. J. Indian Soc. Soil Sci. 24: 263-269.

6. Soil Survey Staff 1993. Soil Survey Manual. USDA Soil Survey Divisions. Agricultural Handbook 18, US Gov. Printing Office, Washington, D.C. p. 437.

7. Jackson ML 1967. Soil Chemical Analysis. Prentice Hall of India Pvt. Ltd. New Delhi.

8. Black CA 1965. Methods of Soil Analysis. Part II. American Soc. Agron. Inc. Medison, Wisconsin, USA.

9. Mehra OP and ML Jackson 1960. Iron oxide removal from soils and clays in a dithionite-citratebicarbonate system buffered with sodium bicarbonate. Clays Clay Miner. 7: 317-327.

10. Jackson ML 1975. Soil Chemical Analysis - Advanced Course. Published by the author. Dept. of Soils.University of Wisconsin, Madison. p. 991.

11. Johnson TL, PR Matelski and CF Engle 1963. Clay mineral characterization of modal soil profiles in several Pennisylvanian countries. Soil Sci. Soc. Amer. Proc. 27: 568-572.

12. Stoops $\mathrm{G}$ and $\mathrm{H}$ Eswaran 1985. Morphological characteristics and wetland soils: Wetland Soils Charaterization, Classification and Utilization. IRRI, Los Banos, Philipines. pp. 177-189.

13. Soil Survey Staff 1999. Soil Taxonomy-A Basic System of Soil Classification for Making and Interpreting Soil Surveys. 2nd ed. Agric. Handb. No. 436. US Govt. Printing Office, Washington, D.C.

14. Fanning DS and VZ Keramidas 1977. Micas. In: Dixon JB and SB Weed(eds). Minerals in Soil Environment.Soil Sci. Soc. Amer. Madison. pp. 159-258.

15. White GN and JB Dixon 2002. Kaolin-serpentine minerals. In: Dixon, J.B. and Schulze, D. G. (eds.) Soil Mineralogy with Environmental Applications. Soil Sci. Soc. Amer. Inc. Madison, Wisconsin. pp. 389-412.

16. White JL 1985. Summary of results of mineralogical study of clay fractions of Bangladesh soils. In: Proceedings of the Workshop on Soil Clay Mineralogy. Bangladesh Agricultural Research Council, Dhaka, Bangladesh. pp. 1-68. 
17. Egashira K and M Yasmin 1990. Clay mineralogical composition of floodplain soils of Bangladesh in relation to physiographic units. Bull. Inst. Trop. Agr., Kyushu Univ. 13:105-126.

18. Moslehuddin AZM and K Egashira 1996. Mineralogical composition of some important paddy soils of Bangladesh. Bull. Inst. Trop. Agr., Kyushu Univ. 19: 33-54.

19. Moslehuddin AZM and K Egashira 1997. Characterization of smectites found in Ganges floodplain soils of Bangladesh. Clay Sci. 10: 151-162.

20. Singh VN and BB Mishra 1994. Sodiumization of some Alfisols in toposequence occurring in IndoGangetic plain of Bihar. J. Indian Soc. Soil Sci. 31(1): 31-37.

(Manuscript received on 29 June, 2010; revised on 8 August, 2010) 